Chen Makranz, MD*

Hiba Qutteineh, MD*

Hanna Bin, PhD

Yaniv Lustig, PhD

John Moshe Gomori, MD

Asaf Honig, MD

Abed El-Raouf Bayya,

MD

Allon E. Moses, MD

Tamir Ben-Hur, MD, $\mathrm{PhD}$

Diana Averbuch, MD

Roni Eichel, MD

Ran Nir-Paz, MD

Correspondence to

Dr. Nir-Paz:

ran.nirpaz@gmail.com
Supplemental data at Neurology.org/nn

\title{
Sandfly virus seroconversion associated with neurologic presentation
}

\section{OPEN}

\section{ABSTRACT}

Objective: To describe the clinical presentation and unique neurologic manifestations of sandfly viruses (SFVs) in the Jerusalem area.

Methods: We identified all patients with acute seroconversion to SFV at the Hadassah-Hebrew University Medical Centers during the years 2008-2013 and retrospectively collected and analyzed the clinical and imaging data.

Results: Nine patients (ranging from 1.5 to 85 years old) were identified. Presentation included acute neurologic disease, mostly with fever, change in consciousness and behavior, seizures, headache, meningitis, limb paresis, or myelitis. Eight patients had clinical signs of meningitis, meningoencephalitis, or encephalitis alone. Four patients had myelitis. MRI identified pathologic symmetrical changes in the basal ganglia, thalami, and other deep structures in 5 patients, and additional myelitis of the spine was noted on imaging in 3 patients. Seven patients had long-term follow-up: 4 completely recovered and 3 had remaining neurologic sequelae, among them 1 with permanent severe brain damage.

Conclusion: Neurologic involvement associated with acute SFV infections is considered to be benign. However, in this series, all 9 patients presented with significant neurologic pathology associated with a unique finding of myelitis and symmetrical basal ganglia, thalami, or white matter involvement. Thus, acute SFV infection should be included in the differential diagnosis in febrile onset of neurologic manifestations and neuroradiologic changes. Neurol Neuroimmunol Neuroinflamm 2016;3:e184; doi: 10.1212/NXI.0000000000000184

\section{GLOSSARY}

EBV = Epstein-Barr virus; FLAIR = fluid-attenuated inversion recovery; SFCV = sandfly fever Cyprus variant; $\mathbf{S F N V}=$ sandfly fever Naples virus; SFSV = sandfly fever Sicilian virus; SFV = sandfly virus; TOSV = Toscana virus; WNV = West Nile virus.

Phleboviruses (sandfly viruses [SFVs]) comprise a genus in the Bunyaviridae family. The human pathogens of Phleboviruses are the sandfly fever Naples virus (SFNV), Toscana virus (TOSV), sandfly fever Sicilian virus (SFSV), and sandfly fever Cyprus variant (SFCV). ${ }^{1}$ Recently a few new members were described, ${ }^{1}$ and Rift Valley fever virus is also a member of this family.

The main vector for SFVs is the Phlebotomine group of sandflies, and Phlebotomus papatasi, $P$ pernisiousus, $P$ arisi, and $P$ perfiliewi are the vectors in the Mediterranean basin. ${ }^{2}$ In Israel, 2 Phlebotomine flies have been documented: $P$ papatasi and $P$ sergenti. ${ }^{3-6}$ A serologic survey in Israel suggested that the prevalence of SFSV and SFNV antibody increases with age, up to $23.7 \%$ (SFSV) and 30.8\% (SFNV). ${ }^{4}$ In geographically adjacent Jordan and Cyprus, the seroprevalence rate ranged from $32 \%$ to $57 \%$ for SFSV and SFNV. ${ }^{7,8}$

The clinical presentation of Mediterranean SFV infection in the Mediterranean basin is thought to be mild in most cases and includes acute nonfatal influenza-like disease. ${ }^{6,9}$ Therefore, it was named "three-day fever," "pappataci fever," and "dengue Mediterranean."

\footnotetext{
*These authors contributed equally to the manuscript.

From the Departments of Neurology (C.M., A.H., T.B.-H., R.E.), Pediatrics (H.Q., D.A.), Radiology (J.M.G.), Medicine (A.E.-R.B.), and Clinical Microbiology and Infectious Diseases (A.E.M., R.N.-P.), Hadassah-Hebrew University Medical Center, Jerusalem, Israel; and Israel Central Virology Lab (H.B., Y.L.), Ministry of Health, Tel Hashomer, Israel.

Funding information and disclosures are provided at the end of the article. Go to Neurology.org/nn for full disclosure forms. The Article Processing Charge was paid by Hadassah-Hebrew University Medical Center.

This is an open access article distributed under the terms of the Creative Commons Attribution-NonCommercial-NoDerivatives License 4.0 (CC BY-NCND), which permits downloading and sharing the work provided it is properly cited. The work cannot be changed in any way or used commercially.
} 


\section{Table 1 Patient characteristics}

\begin{tabular}{|c|c|c|c|}
\hline \multirow[t]{6}{*}{ Parameters } & Demographic & $\begin{array}{l}\text { Median/no. of } \\
\text { patients }\end{array}$ & Range \\
\hline & M:F & $4: 5$ & \\
\hline & Age, y & 30 & $1.5-85$ \\
\hline & Previous known diseases & 5 & \\
\hline & Local resident & 7 & \\
\hline & Warm season & 5 & \\
\hline \multicolumn{4}{|l|}{ Clinical presentation } \\
\hline & $\begin{array}{l}\text { Time from presentation to } \\
\text { admission, } d\end{array}$ & 1 & $1-10$ \\
\hline \multirow[t]{8}{*}{ Manifestations } & Behavioral change & 7 & \\
\hline & Fever & 7 & \\
\hline & Seizures & 7 & \\
\hline & Headache & 3 & \\
\hline & Plegia/paresis & 5 & \\
\hline & Myelitis & 4 & \\
\hline & Opisthotonus & 1 & \\
\hline & Meningitis & 4 & \\
\hline \multirow[t]{16}{*}{ Laboratory results } & WBC, cells $/ \mathrm{mm}^{3}$ & 12,800 & $4,900-18,400$ \\
\hline & LYM, \% & 24.8 & $12.1-84.7$ \\
\hline & PMN, \% & 60.2 & 7.3-88.2 \\
\hline & CSF LYM, cells $/ \mathrm{mm}^{3}$ & 10 & $0-48$ \\
\hline & CSF PMN, cells $/ \mathrm{mm}^{3}$ & 0 & $0-26$ \\
\hline & CSF protein & 279 & $100-3,135$ \\
\hline & CSF glucose & 3.8 & $2-5$ \\
\hline & Leukocytosis & 5 & \\
\hline & Lymphocytosis & 6 & \\
\hline & Neutrophilia & 2 & \\
\hline & Abnormal creatinine & 1 & \\
\hline & Abnormal liver enzymes & 2 & \\
\hline & CSF pleocytosis & 2 & \\
\hline & CSF predominant lymphocytes & 2 & \\
\hline & CSF high total protein & 2 & \\
\hline & CSF normal glucose $(n=7)$ & 6 & \\
\hline EEG & Abnormal EEG $(n=7)$ & 6 & \\
\hline \multirow[t]{2}{*}{ Imaging studies } & Abnormal brain MRI $(n=6)$ & 5 & \\
\hline & Abnormal spinal MRI $(n=3)$ & 3 & \\
\hline \multicolumn{4}{|l|}{ Clinical course } \\
\hline & Length of admission, $d$ & 30 & $8-90$ \\
\hline \multirow[t]{2}{*}{ Outcome (n = 9) } & Alive & 9 & \\
\hline & Neurologic sequelae & 4 & \\
\hline
\end{tabular}

Abbreviations: $\mathrm{LYM}=$ lymphocytes; $\mathrm{PMN}=$ polymorphonuclear cells; $\mathrm{WBC}=$ white blood cell count.

SFV neurologic manifestations were previously mostly associated with TOSV. ${ }^{6}$ Disease presentation includes fever, myalgia, severe frontal headache, vomiting, and neck rigidity associated with meningitis or meningoencephalitis. ${ }^{9,10}$ TOSV infection can also be asymptomatic or present with mild symptoms. ${ }^{9,10}$ However, no focal neurologic or myelopathic manifestations and no abnormalities in CNS imaging have been reported.

Here we report a series of 9 patients in whom acute seroconversion to SFV included severe neurologic involvement.

METHODS The Hadassah-Hebrew University Medical Center is a tertiary medical center in Jerusalem, Israel, with more than 1,000 admission beds in 2 campuses. The medical center provides both inpatient and outpatient care. Primary outpatient care is managed by the patients' health maintenance organizations. Patients who are admitted usually belong to the greater Jerusalem area (more than a million population). The admission area includes the Jordan Valley and Judean regions, the urban area of Jerusalem, and the West Judean foothills, including villages and smaller urban areas. Referrals are also made from adjacent rural and urban communities in the Palestinian authority and from other parts of Israel.

We identified all patients who had an acute seroconversion for SFV during the years 2008-2013. Patients were included only if they had 2 serum samples taken at least 10 days apart. Serology was performed in the Israeli Central Virology Reference Laboratories of the Israeli Ministry of Health using a commercial kit (Euroimmun AG, Lübeck, Germany). Patients were classified as having definite SFV infection if double serology was available and showed a 4-fold rise in titers between the 2 samples or evolvement of new IgG antibodies that suggest acute infection according to the kit manufacturer instructions (table e-1 and figure e- 1 at Neurology.org/nn). All patients had no alternative diagnosis. In all cases extensive evaluation for other possible etiologies (including West Nile virus [WNV]) was negative. Six of 9 patients were eligible for reconfirmation performed at least 1 year following the original test. The chart of each patient was reviewed by at least 2 physicians, and all the available data regarding clinical presentation, neurologic presentation, and demographics were collected.

Standard protocol approvals, registrations, and patient consents. The study was approved by the Hadassah-Hebrew University Ethics Committee (HMO12-0054) as a retrospective study without the need for patient consent.

RESULTS Nine patients with acute seroconversion to SFV were identified (table 1 and table e-1). Patient ages ranged from 1.5 to 85 years old (mean age $=31$ years). Seven patients were living in the eastern part of Jerusalem or east of Jerusalem, and 2 were tourists who came to Jerusalem only 1 week prior to admission and were staying in the same area. Five of 9 cases occurred during the winter (October-January), 1 case occurred during the summer (July), and 3 occurred in the late spring (April-May). Five of the 9 patients had comorbidities (2 had cardiovascular and metabolic syndrome, 1 had cirrhosis and cardiovascular morbidity, 1 had recurrent urinary tract infection, and 1 had a psychiatric disorder).

The main reason for referral to the hospital was meningitis or encephalitic presentation with a change 
in consciousness or in behavior (7 of 9 patients) and with convulsions (6 of 7 patients). One patient who also presented with confusion had nonconvulsive epileptiform activity on EEG. On admission, 6 of 9 patients had fever. Two patients also had thrombocytopenia. The time interval between symptom onset and admission was 1.5 days (median 1; range 1-6 days).

Most patients developed focal neurologic signs during the course of disease. Four patients developed myelitis ( 1 on presentation and the others 7-15 days after disease onset) that presented as flaccid tetraperesis in all with lower limb clonus in 2 patients and hyperreflexia in 1 patient. Five patients had hemiparesis and 1 patient had opisthotonus. Respiratory failure occurred in 5 patients and required mechanical ventilation.

Laboratory evaluation revealed that most of the patients (6 of 9) had mild leukocytosis on presentation (median 12,800 cells $/ \mathrm{mm}^{3}$; range 4,90018,400 cells $/ \mathrm{mm}^{3}$ ). Lymphocytosis was present in 2 patients and thrombocytopenia was present in 2 patients. Lumbar puncture was performed in all $9 \mathrm{pa}$ tients, but only 4 had pleocytosis with predominant lymphocyte count. Only 2 patients had a high level of protein in the CSF (values above $150 \mathrm{mg} / \mathrm{dL}$ ). Glucose level in CSF was normal in all 9 patients.

Brain CT was normal in all patients. Brain MRI was performed in 6 patients and spinal MRI in 4 patients. Brain MRI signal changes were found in 5 patients (table 2, figure 1). Signal changes were characterized by T2/fluid-attenuated inversion recovery (FLAIR) hyperintensities located mainly in the basal ganglia, the thalami, and the white matter bilaterally. White matter T2/FLAIR hyperintensities were found in 3 patients. Corpus callosum involvement was found in 2 patients. Pial enhancement was found in 3 patients. In the most severe case there were bilateral asymmetrical nonenhancing lesions (with restricted diffusion and T2/FLAIR hyperintense lesions) that started in the frontal areas and extended to involve the temporal lobes. Six weeks later, followup brain MRI showed atrophy of those areas, reflecting permanent severe brain damage, and corpus callosum edema with no gadolinium enhancement. This patient ended up with severe irreversible brain damage. Resolution of signal changes on follow-up brain MRI was found in 2 patients, both of whom have had full recovery. None of the patients had hemorrhages or microhemorrhages on $\mathrm{T} 2 *$ sequence.

Spinal MRI was performed in 3 of the 4 patients who had myelitis (table 3 , figure 2). Anterior longitudinal enhancement with T1 gadolinium involving white and gray matter was found in all of these patients. One patient showed enhancement in the entire cervical spine with medullary involvement (figure 2), and 2 showed enhancement in the cervical spine without medullary involvement. Hyperintensity in T2 sequence was found in 2 cases.

The dramatic systemic and neurologic manifestations dictated lengthy hospitalizations. The median length of admission was 30 days (range 8-90 days), and 5 patients were admitted for longer than 1 month.

Seven patients had long-term follow-up. Four patients fully recovered: 2 patients recovered completely before discharge and 2 patients had some neurologic sequelae requiring rehabilitation (most of which improved thereafter). We have follow-up data on 3 of the 4 patients who had myelitis-all recovered completely. The other 3 patients had fixed neurological sequelae. One previously healthy 64-year-old woman developed a short-term memory defect and an abnormal pattern on follow-up EEG. One

\begin{tabular}{|c|c|c|c|c|c|c|c|c|}
\hline \multirow{2}{*}{$\begin{array}{l}\text { Table } 2 \\
\text { Patient }\end{array}$} & \multicolumn{8}{|c|}{ Brain imaging abnormalities by MRI } \\
\hline & Corpus callosum & Basal ganglia & Thalamus & Brainstem & $\begin{array}{l}\text { Internal } \\
\text { capsule }\end{array}$ & $\begin{array}{l}\text { External } \\
\text { capsule }\end{array}$ & $\begin{array}{l}\text { Subcortical } \\
\text { white matter }\end{array}$ & Cortex \\
\hline 1 & $\begin{array}{l}\text { Restricted diffusion } \\
\text { of the splenium }\end{array}$ & $\begin{array}{l}\text { T2 and FLAIR } \\
\text { hyperintensity }\end{array}$ & $\begin{array}{l}\text { T2 and FLAIR } \\
\text { hyperintensity }\end{array}$ & & & & & \\
\hline 4 & & $\begin{array}{l}\text { T2 and FLAIR } \\
\text { hyperintensity }\end{array}$ & & & & & & \\
\hline 5 & & & & $\begin{array}{l}\text { T2 and FLAIR } \\
\text { hyperintensity with } \\
\text { restricted diffusion } \\
\text { and gadolinium } \\
\text { enhancement }\end{array}$ & $\begin{array}{l}\text { T2 and FLAIR } \\
\text { hyperintensity } \\
\text { with restricted } \\
\text { diffusion }\end{array}$ & & & \\
\hline 7 & & & & & $\begin{array}{l}\text { T2 and FLAIR } \\
\text { hyperintensity }\end{array}$ & $\begin{array}{l}\text { T2 and FLAIR } \\
\text { hyperintensity }\end{array}$ & $\begin{array}{l}\text { T2 and FLAIR } \\
\text { hyperintensity }\end{array}$ & \\
\hline 9 & $\begin{array}{l}\text { T2 and FLAIR } \\
\text { hyperintensity with } \\
\text { restricted diffusion } \\
\text { and gadolinium } \\
\text { enhancement }\end{array}$ & & $\begin{array}{l}\text { T2 and FLAIR } \\
\text { hyperintensity } \\
\text { with restricted } \\
\text { diffusion }\end{array}$ & & & & $\begin{array}{l}\text { T2 and FLAIR } \\
\text { hyperintensity } \\
\text { with restricted } \\
\text { diffusion }\end{array}$ & $\begin{array}{l}\text { T2 and FLAIR } \\
\text { hyperintensity } \\
\text { with restricted } \\
\text { diffusion }\end{array}$ \\
\hline
\end{tabular}

Abbreviation: FLAIR = fluid-attenuated inversion recovery. 
Figure 1 Brain MRI characteristics of patients with sandfly virus infection

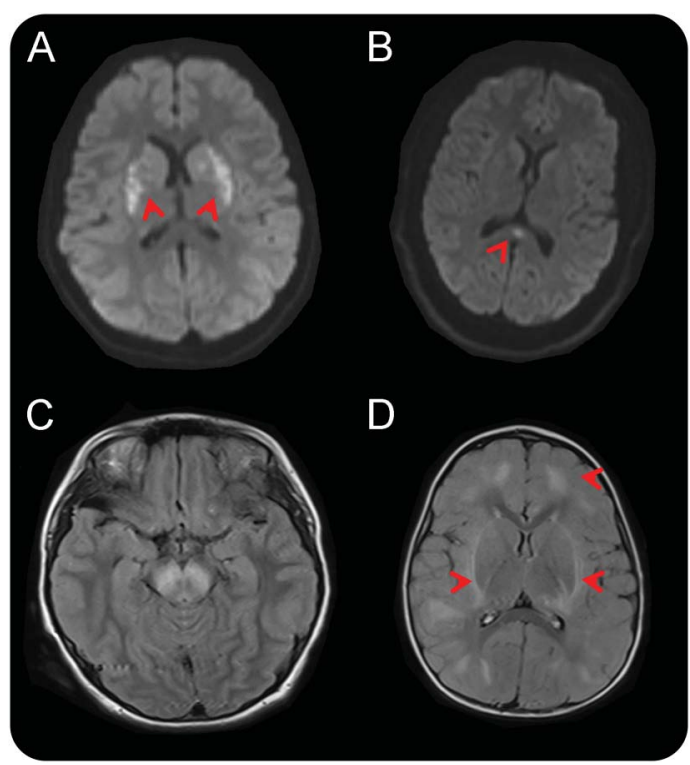

(A) Brain MRI of patient 5 (12 years old) showing bilateral restricted diffusion in the basal ganglia (B) Brain MRI of patient 1 (28 years old) showing restricted diffusion in the corpus callosum splenium. Follow-up MRI after 8 days showed resolution of this lesion (C) Brain MRI of patient 5 (12 years old) showing upper brain stem hyperintensity on T2/fluid-attenuated inversion recovery (FLAIR). (D) Brain MRI of patient 9 (1.5 years old) showing T2/FLAIR hyperintensity in internal capsule, external capsule, and subcortical white matter.

12-year-old girl had tetraplegia and was referred to a rehabilitation center for further treatment. On follow-up 1 year later, she could recognize her relatives but couldn't speak, and she walked with spastic gait. The third patient, a previously healthy 1.5 -yearold child has permanent severe brain damage resulting in severe static encephalopathy, hemiplegia, and uncontrolled seizures.

We also found some asymptomatic seropositive patients. For example, we tested the 5 family members of the patient with the most severe neurologic sequelae (the 1.5-year-old child) for SFV serology. The 2 parents (both positive for $\operatorname{IgM}$ and $\operatorname{IgG}$ ), a twin sister (positive for $\operatorname{IgM}$ and $\mathrm{IgG}$ ), and another sister (positive for IgM) were positive and asymptomatic clinically. Her brother was seronegative.

\section{Table 3 Spinal cord abnormalities on MRI}

\begin{tabular}{|c|c|c|}
\hline Patient & Long tracts & Gray matter \\
\hline 1 & $\begin{array}{l}\text { Symmetrical T2 hyperintensity with } \\
\text { gadolinium enhancement }\end{array}$ & \\
\hline 4 & Symmetrical gadolinium enhancement & $\begin{array}{l}\text { Symmetrical gadolinium } \\
\text { enhancement }\end{array}$ \\
\hline 8 & $\begin{array}{l}\text { Symmetrical T2 hyperintensity with } \\
\text { gadolinium enhancement and restricted } \\
\text { diffusion }\end{array}$ & $\begin{array}{l}\text { T2 hyperintensity with gadolinium } \\
\text { enhancement and restricted } \\
\text { diffusion }\end{array}$ \\
\hline
\end{tabular}

Because of the cross-reactivity between the 4 SFV types available in the kit, it is hard to determine the specific SFV involved (table e-1). However, most of the patients (8 of 9) had seroconversion to either TOSV (6 patients) or SFNV (6 patients). In 7 of 9 patients there was also seroconversion to other SFVs (SFSV in 4 patients, SFCV in 6 patients).

DISCUSSION Here we report a series of 9 patients with an acute severe febrile disease and neurologic manifestations associated with seroconversion to SFV in Jerusalem, Israel. A major observation was that $\mathrm{SFV}$ is present in Jerusalem and its adjacent area, mainly to the east. Also, we identified unique prominent features of severe neurologic manifestations in patients infected with SFV. These included major behavioral and psychiatric manifestations, hemiparesis, myelitis, respiratory failure requiring mechanical ventilation and intensive care unit admission with prolonged recovery, and, in one 1.5-year-old child, permanent severe brain injury. In addition to the severe course of disease, we also report myelitis (in 4 of 9 patients) in association with SFV seroconversion.

Behavioral changes have been reported previously in some patients with SFV infection. ${ }^{11}$ Respiratory failure, ${ }^{12}$ short-term memory defect or other mild cognitive decline, ${ }^{13,14}$ blurred vision and headache, ${ }^{15}$ abducens nerve palsy, ${ }^{15}$ persistent personality changes, ${ }^{12}$ paraparesis, ${ }^{16}$ brain ischemia with paresis and aphasia, ${ }^{17}$ and seizures ${ }^{13}$ have been reported in previous case reports as exceptions to the usual benign disease. However, this study of 9 patients highlights the severe course in most patients with CNS involvement. This is also evidenced by the prolonged recovery process in some patients and the severe fixed sequelae in others.

It is interesting that the severe clinical features were accompanied by only mild CSF pleocytosis. However, they were associated with extensive MRI abnormalities. In most previous reports on SFV infections, no brain abnormality was found by CT or MRI. ${ }^{6}$ We found signal changes on brain MRI, which have never been associated with SFV infection before, in 5 of 6 patients who underwent this test. Those signal changes were located mainly in the basal ganglia, the thalami, and the white matter bilaterally. Brain histology from mice infected with TOSV revealed widespread degeneration and gray matter cell death in deep nuclei and hippocampus. Cortical gray matter showed less severe and focal damage. ${ }^{18}$ In the 1.5 -year-old patient who presented with the most severe clinical manifestations, we found extensive signal changes in cortical and subcortical areas. This finding is similar to an unusual report that documented a hyperintense spot attributable to gliosis 
Figure 2 Spinal MRI characteristics of patients with sandfly virus infection

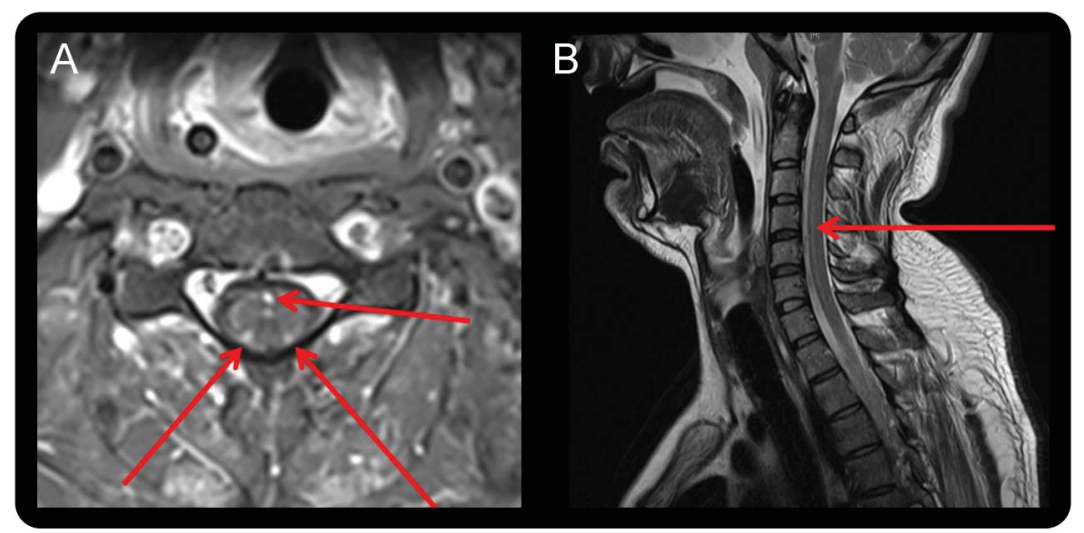

(A) Spinal MRI of patient 1 (28 years old) showing anterior longitudinal T2 hyperintensity of whole cervical spinal cord through the medulla (axial section). (B) Spinal MRI of patient 1 (28 years old) showing anterior longitudinal T2 hyperintensity of whole cervical spinal cord through the medulla (sagittal section).

bilaterally in the frontal subcortical areas. ${ }^{12}$ Similar brain MRI signal changes were reported with other viruses. ${ }^{19}$ For example, bilateral T2/FLAIR hyperintensities of the basal ganglia present in encephalitis caused by Epstein-Barr virus (EBV) and WNV; bilateral thalamic hyperintensities in T2/FLAIR present in encephalitis caused by EBV, WNV, rabies, and influenza virus; brainstem hyperintense lesions are seen with WNV encephalitis and rabies encephalitis; white matter signal changes are seen with influenza virus encephalitis; and transient corpus callosum splenium lesion with restricted diffusion can be seen with EBV encephalitis, WNV encephalitis, and influenza virus encephalitis. As mentioned above, we ruled out other possible viral etiologies in our patients. ${ }^{19}$ This report stresses the possible association of signal changes in the basal ganglia, thalami, and white matter with SFV seroconversion.

Anterior longitudinal enhancement involving white and gray matter was found on spinal MRI. Hyperintensities in the upper spinal cord have been reported with rabies virus ${ }^{19}$ but have not previously been noted to be associated with SFV seroconversion.

Four of 9 (44.4\%) patients were younger than 15 years old. In contrast, in Tuscany, children represented only $10.3 \%$ of TOSV infections during $1990-1995$ in Sienna. ${ }^{20}$ Similarly, during the period $1999-2006$, the seroprevalence rate in Sienna was $19.8 \%$ in adults and $5.8 \%$ in children, suggesting an age-dependent exposure to TOSV and corresponding increased specific immunity. However, this might be attributed to an inherent selection bias in our series because we only reported admitted patients and could not evaluate the real exposure in the community.

In contrast to most of the reports, in which peak incidence of TOSV is in the warmer season, ${ }^{9,11,21}$ in our series there was no association with season: 5 of 9 cases were diagnosed during the warmer months (spring and summer) and 4 were diagnosed during the cold season. However, other arboviruses were found to have climate-dependent transmission, ${ }^{22}$ and in tropical areas, virus transmission can be found throughout the year. In more temperate climates, virus transmission from vector to the host occurs during the warm season. ${ }^{23}$ In Jerusalem, the median temperature during the incubation period was $21.3^{\circ} \mathrm{C}$ (range $16.25^{\circ} \mathrm{C}-26.25^{\circ} \mathrm{C}$ ). Specifically, in cases that have occurred during colder months, the median temperature during the incubation period was $18.95^{\circ} \mathrm{C}$ (range $15^{\circ} \mathrm{C}-22.85^{\circ} \mathrm{C}$ ), only a little different from temperatures in the warmer months. Longer duration of warm weather has been suggested as changing the distribution of 1 of the sandfly species in the vicinity of the Jerusalem urban area and might cause more cases $^{23}$; however, the presence of SFV in this vector still needs to be proven.

It is interesting that 2 of our patients were tourists from nonendemic areas. They had stayed in Jerusalem for a week before onset of symptoms. Because the incubation period of the SFV is $4-8$ days, ${ }^{24}$ they were probably exposed to the virus only after arriving in Jerusalem. It is known that SFV-induced meningitis is less frequent in individuals from endemic zones, probably because of anti-TOSV immunity in the resident adult population. This suggests that tourists from areas where TOSV is not endemic are the target population. ${ }^{6}$

Most of the patients presented here had seroconversion to SFNV serotype, predominantly TOSV. Because our study was hospital-based and involved only patients with neurologic manifestations who required broader investigation, selection bias is possible. This is evidenced by the fact that when we tested all asymptomatic family members of one of the patients we found that most of them (4 out of 5) were seropositive. However, taking into account the extensive neurologic presentation described here, it is possible that there is a need to expand the spectrum of patients that are screened for SFV infection, especially when there are compatible MRI abnormalities, as described in this report.

\section{AUTHOR CONTRIBUTIONS}

Chen Makranz: acquisition of data and analysis, critical revision of the manuscript for important intellectual content. Hiba Qutteineh: acquisition of data. Hanna Bin: acquisition of data and analysis. Yaniv Lustig: acquisition of data and analysis. John Moshe Gomori: acquisition of data and analysis. Asaf Honig: study concept and acquisition of data. Abed El-Raouf Bayya: acquisition of data. Allon E. Moses: critical revision of the manuscript for important intellectual content. Tamir Ben-Hur: critical revision of the manuscript for important intellectual content. Diana Averbuch: critical revision of the manuscript for important intellectual content. Roni Eichel: acquisition of data. Ran Nir-Paz: study concept and design and critical revision of the manuscript for important intellectual content. 


\section{STUDY FUNDING}

No targeted funding reported.

\section{DISCLOSURE}

C. Makranz and H. Qutteineh report no disclosures. H. Bin received travel funding and speaker honoraria from ENIVD and received research support from Ventral Virology Laboratory. Y. Lustig, J.M. Gomori, A. Honig, A. El-Raouf Bayya, and A.E. Moses report no disclosures. T. Ben-Hur is on the scientific advisory board for Kadimastem, Stem Cell Medicine, MAPI Pharma, and Regenera Pharma; is on the editorial board for Journal of the Neurological Sciences, Multiple Sclerosis Journal, and Neurology Research International; holds a patent for use of human embryonic stem cells or cells derived from in neurodegenerative and neuroimmunological disorders; received research support from The British Council, Britain-Israel Research and Academic Exchange, and The Taubman Foundation; and holds stock options in Kadimastem, MAPI Pharma, and Regenera Pharma; D. Averbuch is an associate editor for European Journal of Hematology. R. Eichel reports no disclosures. R. Nir-Paz was a guest editor for Frontiers in Microbiology and is treasurer of the Israeli Society of Infectious Diseases. Go to Neurology.org/nn for full disclosure forms.

Received July 16, 2015. Accepted in final form October 20, 2015.

\section{REFERENCES}

1. Zhioua E, Moureau G, Chelbi I, et al. Punique virus, a novel phlebovirus, related to sandfly fever Naples virus, isolated from sandflies collected in Tunisia. J Gen Virol 2010;91:1275-1283.

2. Peyrefitte CN, Grandadam M, Bessaud M, et al. Diversity of Phlebotomus perniciosus in Provence, southeastern France: detection of two putative new phlebovirus sequences. Vector Borne Zoonotic Dis 2013;13:630-636.

3. Azmi K, Schonian G, Nasereddin A, et al. Epidemiological and clinical features of cutaneous leishmaniases in Jenin District, Palestine, including characterisation of the causative agents in clinical samples. Trans $\mathrm{R}$ Soc Trop Med Hyg 2012;106:554-562.

4. Cohen D, Zaide Y, Karasenty E, et al. Prevalence of antibodies to West Nile fever, sandfly fever Sicilian, and sandfly fever Naples viruses in healthy adults in Israel. Public Health Rev 1999;27:217-230.

5. Faiman R, Abbasi I, Jaffe C, et al. A newly emerged cutaneous leishmaniasis focus in northern Israel and two new reservoir hosts of Leishmania major. PLoS Negl Trop Dis 2013;7:e2058.

6. Dionisio D, Esperti F, Vivarelli A, Valassina M. Epidemiological, clinical and laboratory aspects of sandfly fever. Curr Opin Infect Dis 2003;16:383-388.

7. Batieha A, Saliba EK, Graham R, Mohareb E, Hijazi Y, Wijeyaratne P. Seroprevalence of West Nile, Rift Valley, and sandfly arboviruses in Hashimiah, Jordan. Emerg Infect Dis 2000;6:358-362.

8. Eitrem R, Stylianou M, Niklasson B. High prevalence rates of antibody to three sandfly fever viruses (Sicilian,
Naples, and Toscana) among Cypriots. Epidemiol Infect 1991;107:685-691.

9. Charrel RN, Gallian P, Navarro-Mari JM, et al. Emergence of Toscana virus in Europe. Emerg Infect Dis 2005; 11:1657-1663.

10. Dionisio D, Valassina M, Ciufolini MG, et al. Encephalitis without meningitis due to sandfly fever virus serotype toscana. Clin Infect Dis 2001;32:1241-1243.

11. Jaijakul S, Arias CA, Hossain M, Arduino RC, Wootton SH, Hasbun R. Toscana meningoencephalitis: a comparison to other viral central nervous system infections. J Clin Virol 2012;55:204-208.

12. Serata D, Rapinesi C, Del Casale A, et al. Personality changes after Toscana virus (TOSV) encephalitis in a 49-year-old man: a case report. Int J Neurosci 2011;121: 165-169.

13. Kuhn J, Bewermeyer H, Hartmann-Klosterkoetter U, Emmerich P, Schilling S, Valassina M. Toscana virus causing severe meningoencephalitis in an elderly traveller. J Neurol Neurosurg Psychiatry 2005;76:1605-1606.

14. McMullan LK, Folk SM, Kelly AJ, et al. A new phlebovirus associated with severe febrile illness in Missouri. N Engl J Med 2012;367:834-841.

15. Schwarz TF, Gilch S, Jager G. Travel-related Toscana virus infection. Lancet 1993;342:803-804.

16. Francisci D, Papili R, Camanni G, et al. Evidence of Toscana virus circulation in Umbria: first report. Eur J Epidemiol 2003;18:457-459.

17. Sanbonmatsu-Gámez S, Pérez-Ruiz M, Palop-Borrás B, Navarro-Marí JM. Unusual manifestation of toscana virus infection, Spain Emerg Infect Dis 2009;15:347-348.

18. Cusi MG, Gori Savellini G, Terrosi C, et al. Development of a mouse model for the study of Toscana virus pathogenesis. Virology 2005;333:66-73.

19. Osborn AG. Infection, inflammation, and demyelinating diseases. In: Osborn's Brain: Imaging, Pathology and Anatomy. Philadelphia, PA: Lippincott Williams \& Wilkins; 2012:323-334.

20. Braito A, Corbisiero R, Corradini S, Fiorentini C, Ciufolini MG. Toscana virus infections of the central nervous system in children: a report of 14 cases. J Pediatr 1998;132:144-148.

21. Papa A, Velo E, Bino S. A novel phlebovirus in Albanian sandflies. Clin Microbiol Infect 2011;17:585-587.

22. Hollidge BS, Gonzalez-Scarano F, Soldan SS. Arboviral encephalitides: transmission, emergence, and pathogenesis. J Neuroimmune Pharmacol 2010;5:428-442.

23. Moncaz A, Faiman R, Kirstein O, Warburg A. Breeding sites of Phlebotomus sergenti, the sand fly vector of cutaneous leishmaniasis in the Judean Desert. PLoS Negl Trop Dis 2012;6:e1725.

24. Brett-Major DM, Claborn DM. Sand fly fever: what have we learned in one hundred years? Mil Med 2009;174: 426-431. 


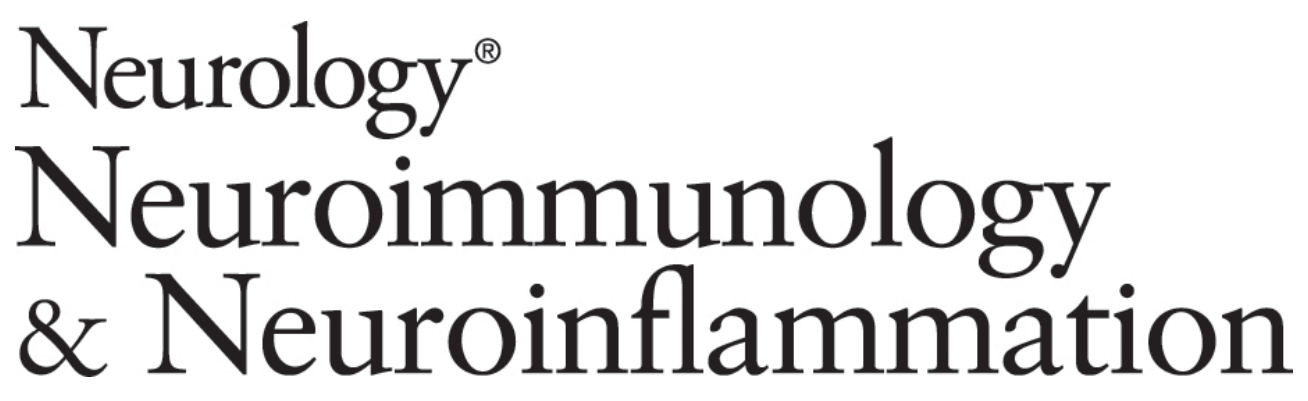

Sandfly virus seroconversion associated with neurologic presentation

Chen Makranz, Hiba Qutteineh, Hanna Bin, et al.

Neurol Neuroimmunol Neuroinflamm 2016;3;

DOI 10.1212/NXI.0000000000000184

This information is current as of December 10, 2015

Neurol Neuroimmunol Neuroinflamm is an official journal of the American Academy of Neurology.

Published since April 2014, it is an open-access, online-only, continuous publication journal. Copyright $\odot$ 2015 American Academy of Neurology. All rights reserved. Online ISSN: 2332-7812.

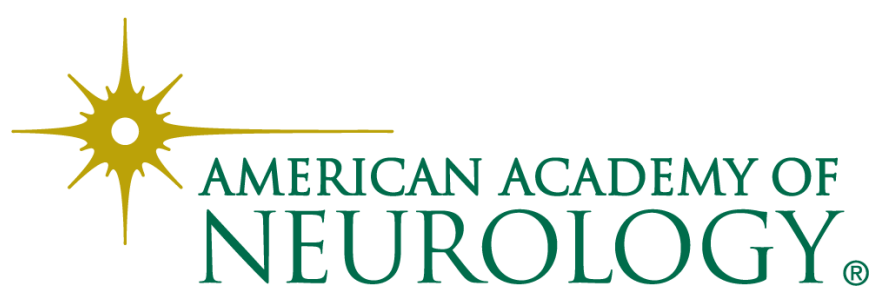




\section{Updated Information \&} Services

\section{Supplementary Material}

\section{References}

Subspecialty Collections

\section{Permissions \& Licensing}

\section{Reprints}

including high resolution figures, can be found at: http://nn.neurology.org/content/3/1/e184.full.html

Supplementary material can be found at: http://nn.neurology.org/content/suppl/2015/12/10/3.1.e184.DC1

This article cites 23 articles, 1 of which you can access for free at: http://nn.neurology.org/content/3/1/e184.full.html\#\#ref-list-1

This article, along with others on similar topics, appears in the following collection(s):

\section{All Infections}

http://nn.neurology.org//cgi/collection/all_infections

Encephalitis

http://nn.neurology.org//cgi/collection/encephalitis

MRI

http://nn.neurology.org//cgi/collection/mri

Natural history studies (prognosis)

http://nn.neurology.org//cgi/collection/natural_history_studies_prognos is

\section{Viral infections}

http://nn.neurology.org//cgi/collection/viral_infections

Information about reproducing this article in parts (figures,tables) or in its entirety can be found online at:

http://nn.neurology.org/misc/about.xhtml\#permissions

Information about ordering reprints can be found online: http://nn.neurology.org/misc/addir.xhtml\#reprintsus

Neurol Neuroimmunol Neuroinflamm is an official journal of the American Academy of Neurology.

Published since April 2014, it is an open-access, online-only, continuous publication journal. Copyright $\odot$ 2015 American Academy of Neurology. All rights reserved. Online ISSN: 2332-7812.

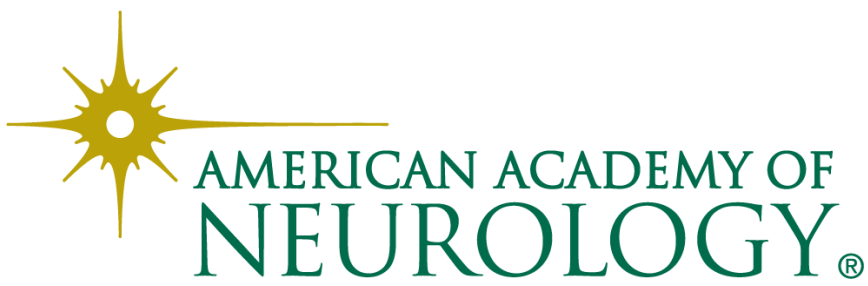

